\title{
Kant and the 'Antinomy' of the Actually Existing Thing
}

\section{The persistence of metaphysics in Kant's critique of the ontological and cosmological arguments}

Anselm's proof of the existence of a being that encompasses all determinations was accepted by many philosophers in the Middle Ages and the Modern Era; among them Duns Scotus, Descartes, Malebranche, Leibniz, Wolff, and Baumgarten. But from the very beginning the "ontological argument", as it was called by Kant, also faced fierce resistance: starting with Gaunilo the list of critics of Anselm's proof includes Thomas Aquinas, William of Ockham, Crusius, Hume and Kant, among many others. As a rule, the criticism of these authors was not aimed at the demonstrability of God's existence - Hume and Kant were exceptions in this respect-, but rather against the particular line of argumentation of the ontological proof. Aquinas' critique epitomizes this position, since he criticizes Anselm's argument, while offering at the same time an alternative proof to demonstrate the existence of God that also relies on existence as such - although not, as it was the case in Anselm's argument, on the existence of the content of a merely mental representation, but on the existence of transitory beings given to perception. The tertia via - known later as argumentum a contingentia mundi or, since Kant, as "cosmological argument" - can be traced back to Plato (Phaedo, 72 c-e; Phaedrus, 245 d-e) and Aristotle (De caelo I 12, 283 a 30, sqq.); however, it is in the context of Scholastic philosophy where that proof was developed in a more consistent way, since the contingency of each existing being was extended then to the totality of existing things by the dogma of the creatio ex nihilo. Throughout the history of philosophy the cosmological argument has had at least as many supporters as the ontological argument; thus, it has also been formulated in many different ways. In a nutshell, the line of reasoning of the cosmological argument is that all things that exist in the universe begin to exist and eventually cease to exist; thus, if contingent things have the possibility both to exist and not to exist, there must be a being that exists necessarily and can for that very reason explain that what does not exist necessarily receives its existence from what exists by itself. 
The sum of things whose appearing and disappearing can be perceived by our minds is, however, limited; thus, what actually functions as the major premise of the cosmological argument are not the things that we perceive and have once perceived, but rather the determinate contents of our mental representations, that is, the contents that can be represented without our mind knowing in that same cognitive act whether they also exist as things of the real world. Precisely because by definition a mental concept does not entail the actual existence of its content, the existence of the actually existing thing whose determinacy is considered by the mind as the same determinacy of the content of the mental concept has to be added extrinsically to their identical determinacy. To elucidate: the content of our mental representations is always determinate; if in given cases - namely when we have mental representations of things that actually exist - the determinacy of the content of our mental representation is the same of the actually existing thing, then existence does not alter in any way their one and the same, common determinacy. Thus, when we have, for example, a mental representation of hundred dollars whose determinacy our mind considers to be the same as the determinacy of something actually existing, i.e. hundred real dollars, existence must be thought of as external or merely accidental to the determinacy as such of hundred dollars. Since the determinacy of the contents of our mental concepts and the determinacy of the real things are in certain cases considered by our mind to be exactly the same - in such cases our mind considers its mental concepts to be concepts of those things -, that such real things actually exist cannot be explained by their common determinacy, because otherwise the contents of the concepts would not be only mental contents, but themselves existing things too. The reason that explains that existing things exist has to be sought, therefore, in a particular existing thing whose determinacy contains now its own actual existence as one of its necessary determinations. Only such necessary being can explain the unity between the determinacy of the existing thing and its existence, since its existence, although it is in fact the own existence of the existing thing, does not, however, belong to it by the fact that that existing thing is precisely that, i.e. such determinate thing.

Kant focused more clearly than anyone before him on the formal inferential structure of the ontological argument. Since in the case of real things of which we have concepts Kant identifies the determinacy of these concepts with the determinacy of those things, existence does not belong for him to determinacy as such (KrV, 219/B 266; A 225/B 273; A 233/B 286; 599-600/B 627-628) (see Engel 1963/1964, 20 -35; Plantinga 1966, 537-545; Hintikka 1981, 128-146; McGrath 1990, 195-212; Everitt 1995, 385-405; Proops 2013, 1-27). Calling into question that existence is a legitimate consequent of a possible inference, Kant disputes the legitimacy of the proof that attempts to derive the existence of an absolutely 
necessary being from its concept as the antecedent of that proof. To elucidate: since existence cannot be a consequent of an inference, in the ontological argument there is no proper argument or inference at all.

Now, unlike the ontological argument, which takes as its starting point the content of a mental concept to infer the existence of a most determinate being, the cosmological argument begins with the transitorily existing things to infer the existence of a necessary being; thus, the cosmological argument seems at first sight to be the opposite of the ontological argument (KrV, A $610-611 /$ B $638-639^{1}$ ). However, on the basis of his conception of existence Kant tries to show that both arguments are intrinsically related to each other. The cosmological argument relies on the consideration of existence as an accidental determination of the determinacy of temporarily existing things: if the determinacy of a temporarily existing thing is identical with the determinacy of the content of a mental concept the reason that explains the existence of that thing cannot be the reason that explains the determinacy that it has in common with the content of the mental concept; the ultimate reason for the existence of the thing that actually exist must be itself an existing thing that includes actual existence as one of the determinations of its own determinacy. But the content of a concept to whose determinacy actual existence belongs necessarily, that is, with other words, the content of a mental concept that needs to be thought of as an actually existing thing is the nervus probandi of the ontological argument. Thus, the cosmological argument is valid only if existence is not external to determinacy, but a possible determination of determinacy, that is, from another perspective, if existence is a real predicate that can be attributed to the content of a concept; the cosmological argument is valid, therefore, only if the ontological argument, which relies on the same conception of existence as a determination, is valid too. ${ }^{2}$ Kant claims, on the contrary, that existence is not a real predicate;

1 "Das Kunststück des kosmologischen Beweises zielt bloß darauf ab, um dem Beweise des Daseins eines nothwendigen Wesens a priori durch bloße Begriffe auszuweichen, der ontologisch geführt werden müßte, wozu wir uns aber gänzlich unvermögend fühlen. In dieser Absicht schließen wir aus einem zum Grunde gelegten wirklichen Dasein (einer Erfahrung überhaupt), so gut es sich will thun lassen, auf irgend eine schlechterdings nothwendige Bedingung desselben." [My emphasis, H.F.]

2 Leibniz had already noticed that Anselm's proof and the argumentum a contingentia mundi are two sides of one and the same argument, but, in contrast to Kant, he considered both proofs to be valid -see Monadologie, $\S \S 44-45$ (G VI 614): 44. Car il faut bien que, s’il y a une realité dans les Essences ou possibilités, ou bien dans les verités éternelles, cette realité soit fondée en quelque chose d'existent et d'Actuel; et par consequent dans l'Existence de l'Etre necessaire, dans lequel l'Essence renferme l'Existence, ou dans lequel il suffit d'être possible pour être Actuel. 45. Ainsi Dieu séul (ou l'Etre Necessaire) a ce privilege, qu'il faut qu'il existe s'il est possi- 
that is why, according to him, existence cannot be contained in any way - neither contingently nor necessarily - in the content of the concept of any object. For this very reason, neither the ontological nor the cosmological argument are for Kant capable of proving what they purport to prove. If existence, as Kant claims, is completely external or, in other words, incommensurably different from the determinate contents of our mental concepts, no inference that takes existence as one of its terms - no matter if it takes it as the consequent, as it is the case in the ontological argument, or as the antecedent, as it is the case in the cosmological argument - can be valid. The alleged proof of the actual existence of a necessary being that resorts to the actually existing things of the world pretends to be the opposite of the ontological argument, which resorts instead to the merely mental concept of a being that, since its determinacy consists in exhaustive determination, has to include actual existence as one of its determinations. As Kant seeks to show, both arguments are only apparently opposing to each other: the conception of existence behind the cosmological argument is the same conception of existence as a determination - i.e. as a real predicate - behind the ontological argument. In the former case, existence is implicitly considered as a contingent determination, while in the latter case it is explicitly considered as a necessary determination.

Despite the fact that the conception of existence as radically different from determinacy invalidates, as Kant claims, both the ontological and the cosmological argument, that same conception of existence results from the correlative conception of the content of the concept as already thoroughgoing determined in its mental state as a merely possible content. As stated above, if the actually existing thing is conceived of as identical to the content of a merely mental concept, its actual existence is expelled by that same identification from the realm of the determinate content and, therefore, it is conceived as radically different from determinacy as such. But the conception of existence as entirely external to determinacy is, along with the correlative conception of determinacy as thoroughgoing determined as purely possible, the condition of possibility of the cosmological argument. Indeed, precisely because every determinate existing thing excludes its own existence from its own determinacy, a specific cause of the fact that it actually exists is required, since the reason that explains that it is that par-

ble. Et comme ríen ne peut empecher la possibilité de ce qui n'enferme aucunes bornes, aucune négation, et par consequent aucune contradiction, cela seul suffit pour connoître l'Existence de Dieu à priori. Nous l'avons prouvée aussi par la realité des verités éternelles. Mais nous venons de la prouver aussi à posteriori puisque des êtres contingens existent, lesquels ne sçauroient avoir leur raison derniere ou suffisante que dans l'être nécessaire, qui a la raison de son existence en luy-même. 
ticular determinate thing cannot explain that it exists. The claim that existence is radically different from the determinacy of the actually existing thing - Kant, as stated above, considers this claim to be the unsurmountable objection against both the ontological and cosmological argument - demands, thus, a specific explanation of the factual existence of that thing, that is to say, it requires an explanation of the determinate existing thing qua existing. This is the reason, by the way, why Aquinas rejected the ontological argument, but accepted the cosmological argument. Aquinas and those who defended the tertia via always insisted that existence is entirely extrinsic to the determinacy of the essence: being lies "outside" (extra) and "beyond" (praeter) essence (Thomas Aquinas, Quodlibet II, q. 2 a. 1 co.; Contra Gentiles, lib. 1 cap. 21, n. 2; Summa Theologiae I, q. 3 a. 4 co.; De potentia, q. 5 a. 3 co.; De veritate, q. 8 a. 8 co.; Super Sent., lib. 2 d. 3 q. 1 a. 1 co.; De ente et essentia, cap. 4). For Aquinas existence is, no less than for Kant, excluded as such from the general realm of determinacy. But it is a fact, however, that there are determinate things which, besides being determinate, also exist. Aquinas thinks therefore that, although one cannot deduce existence from determinacy - that is why he rejects the ontological proof -, one needs nevertheless to suppose a sufficient reason of the existence of those essences that actually exist. Precisely because determinacy is as such only possible, one needs to explain how in the case of actually existing things their determinacy is in fact united with actual existence. Thus, as the mythical ouroboros who eats its own tail, the notion of existence that results from its complete exclusion from the realm of the contents thoroughgoing determined by real predicates requires, precisely because that thoroughness excludes existence, a reason that explains that in the actually existing things their own actual existence is united with their own determinacy. But that same notion of existence as entirely extrinsic to determinacy cancels at the same time, as Kants tries to make clear, the need to seek for a sufficient reason of the existence of what exists, and again for the same reason, namely because since existence is as such excluded from determinacy, the logical laws that are valid for determinacy cannot be applied to existence. To elucidate: since existence is not a determinate content, it cannot be inferred as a determination of any determinate content.

\section{The 'antinomy' of the actually existing thing}

The conflict that derives from the radical distinction between determinacy and existence and the factual unity and interrelation of both in the actually existing thing confronts us with a problem similar to the problem addressed by Kant in the antinomies of pure reason. In the antinomies we also have to deal with a 
state of affairs that requires an explanation, and by the same reason that it requires an explanation that explanation turns out to be impossible. Thus, for example, in the third antinomy the thesis states that freedom exists, because an unconditioned principle is indispensable to explain the whole causal series in the world; to avoid an infinite regress in the series of causes a beginning of the series must be supposed, but the concept of causality that demands, for the whole causal series to take place, a cause that begins that series by itself implies that every cause has in turn a cause (KrV, A 444/B 472). The antithesis of the antinomy rejects, thus, the possibility of an uncaused cause due to the reason that a spontaneous causation is contrary to the law of causality, law that nevertheless requires such cause ( $\mathrm{KrV}$, A 445/B 473).

Hegel criticizes Kant for having reduced the antinomies to only four particular conflicts, and affirms, further, that a deeper analysis of the nature of the cosmological antinomies would have led Kant to become aware that every concept is a unity of multiple determinations, so that two determinations of one and the same concept can eventually be conceived as opposing each other and provoke therefore what could be characterized in broad terms as an "antinomy". According to Hegel, antinomies are not exclusive to rational cosmology, but are the sign of a general conflict that looms in every concept (Hegel, GW 11: 114; GW 21: 180; Enz $§ 48$ Anm.). This conflict relies, more precisely, on the potential mutal confrontation of the internal determinations of a concept when they are conceived in an isolated and abstract way (Hegel, TWA 20: 357-358). In the context of his discussion of Kant's antinomies Hegel explicitly mentions "existence" ( $D a$ sein) as the possible source of an antinomy (Hegel, GW 11: 114; GW 21: 180).

Hegel does not develop his theory of existence in the form of a debate with Kant's antinomies; it is sufficiently clear though that, according to him, one of the main problems that a theory of existence has to deal with is the kind of distinction and relation between existence and determinacy, distinction and relation that for Hegel should not be, by any means, construed in terms of a concurrent dissociation and reunification. When the determinate content of our merely mental representation is identified with the determinacy of the actually existing thing, their now common determinacy is radically dissociated from the existence of the existing thing - in the vocabulary of classical metaphysics: essence is dissociated from being as if each were an aliud with respect to the other (Aquinas, De ente et essentia, cap. 3.7.). ${ }^{3}$ Once determinacy and existence are radically dif-

3 "Omnis autem essentia vel quidditas potest intelligi sine hoc quod aliquid intelligatur de esse suo; possum enim intelligere quid est homo vel Phoenix et tamen ignorare an esse habeat in rerum natura. Ergo patet quod esse est aliud ab essentia vel quidditate.” 
ferentiated from each other and their ultimately artificial difference - for the thing that exists is in fact always one determinate existing thing - is considered as an incommensurable difference, the determinacy of the actually existing thing and its own actual existence can only be re-united in an external way. In this framework, the actually existing thing needs, indeed, to be construed as the result of some kind of "composition" or "synthesis" between intrinsically heterogeneous aspects - namely, determinacy and existence -, aspects which despite being intrinsically heterogeneous are in fact, as it is obvious, united with each other in every actually existing thing. According to this approach, which is the approach of metaphysics as well as of Kant, the existence of the determinate existing thing is entirely different from its determinacy, but it must be simultaneously unified with that same determinacy in order to explain - since determinacy is as such only possible - that that determinate existing thing actually exists. The conception of existence as a determination - i.e. as a real predicate - that Kant harshly criticizes tried to avoid precisely this contradiction by placing from the very beginning existence inside the same ontological domain of determinacy, namely as one of its own possible determinations. The metaphysics of the distinctio realis between being and essence - and de facto Kant himself in his pre-critical period - attempted instead to explain the simultaneous differentiation and reunification of determinacy and existence in the existing things by means of their gratuitous creatio ex nihilo and their continuous conservation in existence by God as Being as such. In Kant's critical period the interpretation of the determinate existing thing as the result of a concurrent division and composition between its own determinacy and its own actual existence does not disappear, but persists: firstly, behind the harsh differentiation between "reality" (Realität) and "existence" (Dasein), respectively, as categories of quality and modality; secondly, behind the consequent conception of existential propositions as subjectively synthetic, and, thirdly, in the claim that, in order to know that something actually exists, that is, in order to know that the thing's determinacy - which is as such only possible - is united with its own existence, the knowing subject has to stumble upon that unity as gratuitously given to an act of perception.

The problem posed by the simultaneous dissociation and reunification between determinacy and existence in the actually existing thing relies, however, on a set of debatable logical operations: firstly, on the identification of the determinacy of the actually existing things with the determinate content of certain mental concepts that the mind considers to be the appropriate concepts of those things; secondly, on the consequent interpretation of determinacy as in itself only possible, and, ultimately, on the consideration of the difference between determinacy and existence as an absolute difference. The criticism of 
this set of logical operations leads to the rejection of the radical differentiation between the determinacy of the actually existing thing and the fact that it exists. But since in that paradigm determinacy is as such only possible - that is, in principle only the content of a merely mental concept -, the criticism of its absolute differentiation with respect to existence leads, further, to reject the radical distinction between rationality as a one-sided property of the knowing subject and the world as a transcendent realm that is unknowable to merely subjective reason. Such criticism, which is one of the main objectives of post-Kantian idealism leads, thus, to abandon not only the dualism between a necessary being and the world as the totality of the contingent (possible) contents actualized (posited) by that being, but also - and for the same reason - the dualism between the human mind as the realm of only possible determinacy and the real world as the realm of the "absolute position" of determinacy (BDG, AA 2: 73.24-25; KrV, A 598-599/B 626-627; FM, AA 20: 303.15-164). Post-Kantian idealism embraces Kant's philosophical insights on how we know the determinate things that exist in the real world, but aims to solve with new and sharper conceptual tools the still open problems posed by Kant's transcendental approach.

\section{Bibliography}

Aquinas, Thomas (1992): Opera Omnia. Cum hypertextibus in CD-ROM. Roberto Busa (Ed.), Milano: Editoria Elettronica Editel.

Aristotle (1922): "De caelo". In: The works of Aristotle. Translated into English [under the editorship of J. A. Smith and W. D. Ross]. Vol. 2. J. L. Stocks (Ed.). Oxford: The Clarendon Press.

Engel, S. Morris (1963/1964): “Kants 'Refutation' of the Ontological Argument”. In: Philosophy and Phenomenological Research 24, 20-35.

Everitt, Nicholas (1995): “Kant's Discussion of the Ontological Argument”. In: Kant-Studien 86, 385- 405.

Hegel, Georg Wilhelm Friedrich (1968ff): Gesammelte Werke, Eds.: Rheinisch-Westfälische Akademie der Wissenschaften in association with the Deutsche Forschungsgemeinschaft. Hamburg: Felix Meiner. [= GW]

4 See also OP, AA 21: 571.19-20; OP, AA 22: 549.11-13; V-Met/Herder, AA 28: 128.32-33; 132.09-10; 133.35-37; 151.12-13; V-Met/Heinze, AA 28: 313.16-25; V-Met/Volckmann, AA 28: 412.32-39; 413.19-37; 455.13-18; V-Met-L2/Pölitz, AA 28: 598.31-36; V-Met/Dohna, AA 28: 629.24-28; 630.01-05; 633.23-24; 693.17-20; V-Met-K2/Heinze, AA 28: 722-723.33-10; 723.23-25; 783.17-22; 784.29-35; V-Met-N/Herder, AA 28: 913.13-19; 916.25-26; 918.13-16; 936.17-20; 955.25-26; 957.26-28) 
Hegel, Georg Wilhelm Friedrich (1969): “Enzyklopädie der philosophischen Wissenschaften im Grundrisse”. In: Hegel, Werke in zwanzig Bänden. Theorie-Werkausgabe. Vols. 8-10. Eva Moldenauer, Karl M. Michel (Eds.). Frankfurt am Main: Suhrkamp. [= Enz]

Hegel, Georg Wilhelm Friedrich (1969): "Vorlesungen über die Geschichte der Philosophie III". In: Hegel, Werke in zwanzig Bänden. Theorie-Werkausgabe. Vol. 20. Eva Moldenauer, Karl M. Michel (Eds.). Frankfurt am Main: Suhrkamp. [= TWA]

Hintikka, Jaako (1981): "Kant on Existence, Predication, and the Ontological Argument". In: Dialectica 35, 128-146.

Leibniz, Gottfried Wilhelm (1875ff): Die philosophischen Schriften von Gottfried Wilhelm Leibniz. Carl Immanuel Gerhardt (Ed.), 7 vols., Berlin: Weidmannsche Buchhandlung. $[=\mathrm{G}]$

McGrath, Patrick J. (1990): "The Refutation of the Ontological Argument". In: The Philosophical Quarterly 40 (159), 195-212.

Plantinga, Alvin (1966): “Kant's Objection to the Ontological Argument”. In: Journal of Philosophy 63, 537-545.

Plato (1997): Complete Works. John M. Cooper (Ed.). Indianapolis: Hackett.

Proops, Ian (2013): “Kant on the Ontological Argument”. In: Nous 49 (1), 1-27. 